\title{
КАФЕДРА ИСТОРИИ МОСКОВСКОГО ГУМАНИТАРНОГО УНИВЕРСИТЕТА
}

\author{
С. В. Алексеев \\ (Московский гуманитарный университет)
}

\begin{abstract}
Аннотация: Очерк истории и основных направлений научно-исследовательской деятельности кафедры истории Московского гуманитарного университета.

Подготовлено на основе доклада автора на Всероссийской научной конференции "Военная история России», которая прошла в Московском гуманитарном университете 25 апреля 2016 г.

Ключевые слова: Московский гуманитарный университет; историческая наука; научные школы; высшее образование
\end{abstract}

\section{DEPARTMENT OF HISTORY OF MOSCOW UNIVERSITY FOR THE HUMANITIES}

\author{
S. V. Alekseev \\ (Moscow University for the Humanities)
}

\begin{abstract}
This is a short summary of the history and main directions of research of the Department of History of the Moscow University for the Humanities.

This text has been originally presented as a paper at "The military history of Russia" conference, which was held at Moscow University for the Humanities on April 25, 2016.

Keywords: Moscow University for the Humanities; historical scholarship; research schools; higher education
\end{abstract}

Кафедра истории Московского гуманитарного университета ведет свою собственную историю с 1992 г., когда была создана кафедра истории Института молодежи (об истории кафедры подробнее см: Алексеев, 2011: Электр. ресурс). Первым заведующим кафедрой истории стал доктор исторических наук, профессор Анатолий Акимович Королев. 1 июня 2010 г. заведующим кафедрой назначен доктор исторических наук С.В.Алексеев. Таким образом, непрерывная история кафедры истории на сегодня насчитывает 24 года.

Кафедра изначально складывалась как коллектив разносторонних специалистов, занимавшихся изучением подчас существенно расходящихся, 
трудно сводимых к общему знаменателю научных проблем. С первых лет своей истории кафедра истории Московского гуманитарного университета разрабатывала различные аспекты исторической науки, связанные как с отечественной, так и со всеобщей историей. Среди трудов преподавателей - монографические работы и учебные пособия, посвященные средневековой и новой истории России, истории зарубежных стран, международных отношений, истории культуры и религии, историософии, исторической психологии. Все это ставило перед научным коллективом задачу вычленения общих интересов, определения точки концентрации, которая способствовала бы совместному творческому поиску.

Такая тематика была в итоге найдена. Общекафедральная научная тема сформулирована как «Социокультурные аспекты отечественной и всеобщей истории».

Таким образом, кафедра разрабатывает как традиционные исторические сюжеты (политическая и экономическая история), так и сюжеты «не традиционные», но все более входящие в обиход большой науки. Среди них - темы, связанные с историей культур и цивилизаций, русского национального характера, ментальности. «История ментальности» - одно из магистральных направлений научной работы кафедры. Кроме него, кафедра разрабатывает основные комплексные исследовательские темы: «Демифологизация истории России» и «Социокультурные аспекты отечественной и всеобщей истории».

Преподаватели кафедры изучают неизвестные и малоизвестные проблемы истории, в том числе и привлекающие большое общественное внимание. Их работы посвящены разным эпохам - от древнейших этапов истории славян до новейшей истории России и мира.

В 2010-2014 гг. было проведено три всероссийские научные конференции «Элита России в прошлом и настоящем: социально-психологические и исторические аспекты». Конференции проводились совместно с кафедрой психологии и педагогики Российского университета дружбы народов (РУДН). По их итогам выходили одноименные сборники научных статей (Элита России ... , 2010, 2012; Историческое обозрение, 2014). С 2010г. кафедра совместно с Центром исторических исследований Института фундаментальных и прикладных исследований МосГУ организует работу секции «Проблемы исторического образования» в рамках ежегодной международной научной конференции «Высшее образование для XXI века».

На кафедре истории сложился одаренный творческий коллектив, в котором представлены разные поколения специалистов. На 2015/16 учебный год на кафедре работает 5 докторов и 5 кандидатов исторических наук. 5 штатных сотрудника кафедры имеют ученое звание профессора, 3 - доцента. 
Первый заведующий кафедрой истории А. А. Королев (род. 1940) доктор исторических наук, профессор, Заслуженный деятель науки РФ. А.А. Королев является специалистом в области истории и теории молодежной политики общественно-политических организаций и государственных органов. В круг его научных интересов входят проблемы истории, методологии, историософии, историографии, социологии, культурологии, религии, психологии, науковедения. Помимо упомянутого выше авторского спецкурса «История и психология» А. А. Королев читает курсы «Отечественная история», «Геополитическое положение России в современном мире», совместно с преподавателями кафедр философии, культурологии и политологии и регионоведения разработал и читает курс «Глобалистика»».

А. А. Королев - заслуженный деятель науки Российской Федерации, почетный работник высшего профессионального образования РФ, лауреат конкурса «Лидер в образовании - 2003» в номинации «Лучший заведующий кафедрой», награжден серебряной медалью имени Н. Н. Моисеева «За заслуги в образовании и науке», медалью «К 850-летию Москвы», орденом МосГУ «Честь и служение» I степени. А. А. Королев награжден также медалью Союза советских офицеров «За верность присяге», медалью воина-интернационалиста, медалью «20 лет вывода советских войск из Афганистана» и другими наградами СССР, Российской Федерации, Республики Афганистан.

А. А. Королев - автор более 250 научных, учебно-методических, научно-популярных работ. Помимо этого, А. А. Королев являлся составителем и ответственным редактором подготовленных на кафедре сборников научных статей. Под руководством и при участии А. А. Королева создан учебно-методический комплекс по курсу «Отечественная история». Основные работы А. А. Королева за последние годы связаны с историкопсихологической проблематикой (Журавлев, Кольцова, Королев, 2011; Королев, 2011).

Доктор исторических наук, профессор Ю. А. Васильев (род. 1958), работал в Высшей комсомольской школе (ВКШ) с 1989 г., а на кафедре с момента ее сформирования. Он специализируется в области социальной и экономической истории, историософии. Ю. А. Васильев имеет более 170 публикаций, в том числе монографии, учебники, учебные пособия. Они посвящены различным проблемам новейшей российской и мировой истории, философии истории, истории российского крестьянства, социальной и культурной проблематике. Из последних работ следует отметить монографии, посвященные восстаниям русского крестьянства в годы «военного коммунизма» (Алешкин, Васильев, 2012), истории русской исторической школы (Васильев, 2012а), военной биографии Ю. В. Андропова (Васильев, 2012b). 
Основные направления исследований доктора исторических наук, профессора М. М. Мухамеджанова (род. 1936) - археография, источниковедение, история молодежной политики, социальных движений в России и в мире. На кафедре истории он работает с 1993 г. М. М. Мухамеджанов - автор более 200 научных публикаций, в том числе ряда новейших работ по истории комсомола (Васильев, Мухамеджанов, 2008; Мухамеджанов, Ручкин, 2008; см. также: Мухамеджанов, 2006). М. М. Мухамеджанов награжден медалями «За трудовую доблесть» (1981), «Ветеран труда» (1996), «850-летие Москвы» (1997).

Большой вклад в научно-исследовательскую деятельность кафедры, в смычку этой деятельности с учебным процессом вносят и другие преподаватели. Среди них можно выделить кандидата исторических наук, члена Союза писателей России, автора более 300 работ по истории России XVIII-XIX вв. О. И. Елисееву (напр.: Елисеева, 2014, 2015).

На данный момент на кафедре истории сложились и активно работают научные школы, основными направлениями исследований которых являются цивилизационные аспекты российской и мировой истории, история ментальностей, история религии, взаимодействие культурноисторических процессов. На кафедре работают специалисты по различным периодам отечественной и мировой истории: средневековой (С.В.Алексеев, А. А. Инков), новой (А. А. Королев, О. И. Елисеева, Г. С. Амрахова), новейшей (Ю. А. Васильев, А. А. Королев, М. М. Мухамеджанов, Д.Д. Пеньковский, Л. Ю. Тихомирова, О. Г. Жукова). Все преподаватели кафедры принимают участие в ее научной работе: публикуют научные статьи, большинство имеют опубликованные или переизданные за последние годы монографии.

За свою историю кафедра организовала - как самостоятельно, так и в сотрудничестве с другими научными организациями и подразделениями университета, - немало научных мероприятий. Среди них - I, II и III научные конференции «Элита России в прошлом и настоящем: социальнопсихологические и исторические аспекты» (июнь 2010, апрель 2012, апрель 2014), научная конференция «Групповая идентичность в истории и культуре: этнос, религия, социальный организм» (апрель 2011), конференция «У истоков модернизации: кризис средневекового общества на Востоке и Западе Европы» (2013 г.), круглый стол «Влияние исторических фальсификаций и мифов на сознание и социальное поведение современной российской молодежи» (2015 г.), конференция «Военная история России» (2016 г.).

Для ученых-историков и преподавателей истории дополнительные вызовы связаны с изменением общественно-политической повестки дня, с обострением идейной борьбы на поле исторической науки. Как отмечалось в рекомендациях круглого стола, посвященного проблемам демифо- 
логизации истории России и прошедшего в Московском гуманитарном университете в сентябре 2014 года, «в российском обществе, в том числе образованном, отсутствует консенсус по важнейшим проблемам отечественной истории. Дискуссии по исторической проблематике, вольно или невольно инициированные в последние годы различными политическими кругами, не только не привели к выработке единого подхода, но и породили негатив в общественно-политической сфере. Они стали дополнительным фактором для развития политического радикализма разных толков, а характерные для них ностальгические поиски идеалов в том или ином прошлом способствовали росту неудовлетворенности сегодняшним днем без предъявления реальных, обращенных в будущее альтернатив. Насущной необходимостью является снижение градуса подобного рода дискуссий, а с другой стороны - выработка целостного и взвешенного подхода к истории Отечества, который мог бы стать элементом государственной идеологии».

В свете этого задачи демифологизации, взвешенного и объективного подхода к истории Отечества различных периодов, гражданскопатриотического воспитания историей становятся во главу угла для российских ученых-историков, преподавателей истории, в определенном смысле для всех специалистов-гуманитариев. Образец такого подхода представлен реализацией в 2013-2014 гг. научного проекта «Демифологизация истории России XX века» под руководством Ректора Московского гуманитарного университета, доктора философских наук, профессора И.М.Ильинского. В реализации проекта приняли активное участие специалисты кафедры истории, использующие накопленный опыт в процессе дальнейшей научной работы. По итогам проекта издана коллективная монография, в подготовке которой приняли участие преподаватели кафедры: С.В.Алексеев, Г.С. Амрахова, О.Г. Жукова, А. А. Королев, М.М.Мухамеджанов (Россия ..., 2014). В 2015 г. под редакцией С. В. Алексеева выпущена коллективная монография по итогам научного проекта «Влияние исторических фальсификаций и мифов на сознание и социальное поведение современной российской молодежи (Алексеев и др., 2015).

Кафедра плодотворно сотрудничает с целым рядом крупнейших научных центров, в т. ч. с Институтом российской истории РАН, МГУ им. М.В.Ломоносова, МПГУ, РУДН, Финансовым университетом Правительства РФ, РАНХиГС при Президенте РФ, РИСИ и др. Из общественных научно-просветительских организаций кафедра сотрудничает с Историко-просветительским обществом «Радетель» (председатель - заведующий кафедрой С. В. Алексеев, ответственный секретарь - доцент кафедры О. И. Елисеева).

В течение последних пяти лет на научно-исследовательскую рабо- 
ту кафедры и ее преподавателей использовались средства, выделенные РГНФ (в числе грантополучателей: А. А. Королев - 2010 г., руководитель проекта; С. В. Алексеев - 2010 г., исполнитель проекта, с 2013 г. реализует проект индивидуального исследования), и Президентской программы поддержки НКО (С. В. Алексеев, Ю. А. Васильев, А. А. Королев, М. М. Мухамеджанов, О. Г. Жукова, Г. С. Амрахова - исполнители проекта, реализованного Центром образовательных технологий; С. В. Алексеев - руководитель проекта, реализуемого университетом).

За последние пять лет работы преподавателей кафедры издавались в издательствах «Вече» (С. В. Алексеев, Ю. А. Васильев, О. И. Елисеева, А.А.Инков, О. Г. Жукова), «Молодая гвардия» (С. В. Алексеев, О. И. Елисеева). Это доказывает перспективность разработок преподавателей, заинтересованность в них издателей.

Ряд преподавателей кафедры являются членами и руководителями редакционных органов научных периодических изданий, в том числе входящих в перечень рецензируемых изданий ВАК. Профессора С.В.Алексеев, А. А. Королев, Д. Д. Пеньковский являются членами редакционной коллегии журнала «Знание. Понимание. Умение». Профессор А. А. Королев является членом редакционного совета, профессор С. В. Алексеев - членом редколлегии журнала «Научные труды Московского гуманитарного университета». Профессор Ю. А. Васильев является членом редсовета журнала «Полиграфист» (издание в списке ВАК) и журнала «Вестник Российского философского общества», редколлегии журнала «Власть». Заведующий кафедрой д.и.н. С. В. Алексеев является главным редактором ежегодного альманаха «Историческое обозрение». В редакционную коллегию альманаха входят доценты кафедры О. И. Елисеева и А. А. Инков (ответственный секретарь), в редакционный совет - проф. А. А. Королев (председатель), проф. Ю. А. Васильев, проф. Д.Д. Пеньковский.

С учетом публикационной активности и реальных достигнутых результатов можно выделить следующие перспективные направления научных исследований кафедры:

1. Мифологизация и демифологизация новейшей истории России: поли-тические и научные аспекты;

2. Средневековая история славянских народов и Руси: источники и их интерпретация;

3. Спорные вопросы и мифы истории Российской империи.

Следует подчеркнуть, что при реализации любых направлений исследований залогом их актуальности является непосредственное обращение к историческим источникам. Выявление, публикация и интерпретация первоисточников признается основным или даже единственным подлинным направлением фундаментальных исследований в исторической 
науке как в России, так и за рубежом. Соответственно, приоритетным направлением для научной работы кафедры становится именно работа с источниками - выявление и введение в научный оборот новых источников, публикации, переводы, комментирование, написание научных работ на прочной источниковой базе.

\section{СПИСОК ЛИТЕРАТУРЫ}

Алексеев, С. В. (2011) Кафедра истории Московского гуманитарного университета: кадры, история, научные школы [Электронный ресурс] // Информационный гуманитарный портал «Знание. Понимание. Умение». № 2. URL: http://www.zpu-journal.ru/e-zpu/2011/2/Alekseev_History_ Department/ (дата обращения: 20.04.2016).

Алексеев, С. В., Гневашева, В.А., Луков, С. В., Плотникова, О.А., Ручкин, Б. А. (2015) Историческое сознание российской молодежи. М. : Московский гуманитарный университет.

Алешкин, П. Ф., Васильев, Ю. А. (2012) Крестьянские восстания в России в 1918-1922 гг.: от махновщины до антоновщины. М. : Вече.

Васильев, Ю.А. (2012а) Теория и методы в русской исторической школе. М. : УРСС.

Васильев, Ю. А. (2012b) Тайны «Могикана»: к 100-летию со дня рождения Ю. В. Андропова. М.: Московский гуманитарный университет.

Васильев, Ю. А., Мухамеджанов, М. М. (2008) История Центральной комсомольской школы: к 100-летию создания ВЛКСМ. М. : Московский гуманитарный университет.

Елисеева, О. И. (2014) Повседневная жизнь русских литературных героев XVIII - первой трети XIX в. М. : Молодая гвардия.

Елисеева, О. И. (2015) Радищев. М. : Молодая гвардия.

Журавлев, А. Л., Кольцова, В. А., Королев, А. А. (2011) История и психология: неумолчный диалог. М.: Московский гуманитарный университет.

Историческое обозрение (2014). Вып. 15. М.: Национальный институт бизнеса.

Королев, А. А. (2011) Этноменталитет: предмет, структура, методы. М.: Московский гуманитарный университет.

Мухамеджанов, М. М. (2006) Избранные статьи. М. : Московский гуманитарный университет.

Мухамеджанов, М. М., Ручкин, Б. А. (2008) Уроки комсомола: к 90летию ВЛКСМ. М. : Московский гуманитарный университет.

Россия. ХХ век. История. Мифы. Память (2014). М. : Московский гуманитарный университет.

Элита России в прошлом и настоящем: социально-психологические и исторические аспекты (2010). М.: Московский гуманит. университет.

Элита России в прошлом и настоящем: социально-психологические 
и исторические аспекты (2012). М.: Национальный институт бизнеса.

Дата поступления: 15.06.2016 г.

Алексеев Сергей Викторович - доктор исторических наук, профессор, заведующий кафедрой истории Московского гуманитарного университета, председатель правления Историко-просветительского общества «Радетель». Адрес: 111395, Россия, г. Москва, ул. Юности, д. 5, корп. 3. Тел.: +7 (499) 374-55-81. Эл. адрес: ipo1972@mail.ru

Alekseev Sergey Viktorovich, Doctor of History, Professor and Chair, Department of History, Moscow University for the Humanities; Chairman, Radetel Historic-Educational Society. Postal address: Bldg. 3, 5 Yunosti St., 111395 Moscow, Russian Federation. Tel.: +7 (499) 374-55-81. E-mail: ipo1972@mail.ru 